\title{
Arrogance imperils plans for change at Harvard
}

\section{An abrasive president may find it counterproductive to alienate so much of the faculty.}

Sir - I was disappointed by your recent Editorial ("Why Harvard needs Summers" Nature 434, 1; 2005), published in the aftermath of Harvard president Larry Summers' suggestion that women fail to advance in science because they are innately less able than men. His comments have done incalculable harm, contributing greatly to the hostile environment that causes women to leave science.

Summers' views are opposed by an avalanche of data showing that women are as capable as men in science, but often cannot succeed by merit alone because of prejudice. One study $(\mathrm{C}$. Wennerås and A. Wold, Nature 387, 341-343; 1997) found that women applying for a research grant needed to be 2.5 times more productive than men in order to be considered equally competent; for many more, see Why so Slow? by Virginia Valian (MIT Press, Cambridge, MA, 1999). No wonder women are not succeeding! Summers' views amount to blaming the victim.

As Stephen Jay Gould's wonderful book The Mismeasure of Man (Norton, New York, 1996) shows, theories about the supposed innate inferiority of women and minorities invariably derive from social prejudice. Many well-meaning people have these biases and are unaware of them. We all need to be more aware of our social biases, and we all need to speak out and confront sexism and discrimination whenever we encounter them.

For this reason, I have been disappointed by the failure of our, largely male, scientific leadership to speak out about the inaccuracy of Summers' comments. "Qui tacet consentire videtur: he who keeps silent is assumed to consent" - and the silence has been deafening. It is difficult for women scientists: if they speak out, they are viewed as asking for undeserved benefits, whereas if they keep silent, progress cannot be made. That's why I think the MIT professor who brought Summers' comments to public attention, Nancy Hopkins, is a hero.

At this point, Summers' arrogant and unscholarly approach has so deeply antagonized the Harvard faculty that there is little chance he can achieve the positive changes enumerated in your Editorial.

Ben A. Barres

Department of Neurobiology, Stanford University School of Medicine, 299 Campus Drive, Stanford, California 94305-5125, USA

\section{DNA barcoding is no substitute for taxonomy}

Sir - DNA barcoding, formerly a way of identifying DNA within foodstuffs, is now being proposed as a way to catalogue life.

At the First International Barcoding Conference, held at the Natural History Museum in London in February 2005, heads of research institutes discussed plans to use museums, herbaria and other biodiversity institutes as national centres for DNA barcoding. Several small grants promoting it as an economical way of cataloguing life have been awarded, with a view to seeding bids for larger consortium grants.

Claims for its benefits are extravagant. The Consortium for the Barcode of Life has stated: "DNA barcoding will make a huge difference to our knowledge and understanding of the natural world." But that's a slogan. What of the science behind these undertakings?

The purpose of barcoding is to find a unique piece of DNA (cytochrome $c$ oxidase subunit 1 , for example) for every described species, so future taxonomists can run large biotic surveys without the need to learn or use morphological keys. Barcoding is at best a technology that may be able to spot DNA diversity within physically indistinct species. But even at this level it remains a genetic key to identify known species, rather than replacing traditional taxonomic practice.

However, this quick, cheap technology is in competition with taxonomy for funding. What cash-strapped student will want to enter a field such as taxonomy that takes years to master and offers little or no job prospects? A budding barcoder — with no interest in biology, let alone taxonomy - can be trained in a fraction of that time, quickly disseminate their 'research' globally and look forward to a well-funded career.

DNA barcoding may seem progressive to those who use the word 'dusty' whenever the subject of taxonomy arises. But the work of taxonomists provides knowledge of the organism, not a few possibly unique nucleotides. In any case, every barcode must be linked with a known, described specimen stored somewhere.

Given its high-profile launch, barcoding will almost certainly result in a plethora of newly 'flagged' DNA species that will never be formally described. One estimate is that it will take some 250 years for taxonomy to catch up with barcoding. True to form, barcoding has supplied an answer: 'DNA taxonomy' - cataloguing barcodes and assigning each to an unnamed species.

Traditional taxonomy cannot keep up with this 'diversity'. How long will it be until even the specimen is no longer necessary to 'understand' the organism?

DNA barcoding generates information, not knowledge. The vast number of barcodes will tell us what we know: life is complex. Museums that encourage DNA barcoding to compete for funding with taxonomy are misguided, as the practice is counterproductive to furthering our understanding of life.

Malte C. Ebach ${ }^{\star}$, Craig Holdrege $\dagger$

${ }^{*}$ Buffalo Museum of Science, 1020 Humboldt

Parkway, Buffalo, New York 14211, USA

$\dagger$ The Nature Institute, 20 May Hill Road,

Ghent, New York 12075, USA

\section{Don't mix radiocarbon and calendar years}

Sir - Your News Feature "Skeleton keys" (Nature 433, 454-456; 2005) contains two statements that, together, are misleading. First, it is stated that "Clovis people had made it to the southwestern United States by 11,500 years ago", and second, that Kennewick man is "a 9,000-year-old human skeleton”.

So Kennewick man lived 2,500 years after Clovis? No, in fact, he lived some 4,000 years after (see M. A. Jobling, M. E. Hurles and C. Tyler-Smith Human Evolutionary Genetics, Garland Science, New York, 2004).

The confusion arises because the Clovis date is in radiocarbon years, whereas the Kennewick date appears to be somewhere between radiocarbon and regular calendar years: 8,400 radiocarbon or 9,300-9,500 calendar (see www.cr.nps.gov/aad/ kennewick/c14memo.htm).

Radiocarbon years differ from calendar years because the amount of ${ }^{14} \mathrm{C}$ in the atmosphere has varied considerably in the past. So the quoted Clovis date of 11,500 years corresponds to approximately 13,500 calendar years.

Please be consistent, and stick to calendar dates so that non-specialists can understand.

Chris Tyler-Smith*, Matthew E. Hurles*, Mark A. Jobling $\dagger$

* The Wellcome Trust Sanger Institute, Wellcome Trust Genome Campus, Hinxton, Cambridgeshire CB10 1SA, UK $\dagger$ Department of Genetics, University of Leicester, University Road, Leicester LE1 7RH, UK 